\title{
Small and Medium Sized Enterprises Development under Trade Liberalisation: A Survey of Nigerian Experience
}

\author{
Obokoh, Lawrence Ogechukwu (ACA) (Corresponding Author) \\ School of Management and Business, Cledwyn Building, Penglais Campus, University of Wales
}

Aberystwyth, SY23 3DD

E-mail: Lechukwu2001@yahoo.com

\begin{abstract}
This study reviews the policies implemented by the Nigerian government over the years to assist the development of manufacturing small and medium sized enterprises (SMEs) in Nigeria following the implementation of Trade liberalisation policy in 1986. The aim of the liberalise trade policy was to encourage competition and improve efficiency in the use of local resources; yet most Nigerian SMEs still find it difficult to compete and merely struggle to survive the liberalised economic environment in Nigeria. The result of the study of a sample of 500 manufacturing SMEs operating in Lagos State reveals that despite the laudable policies, the effects are not felt by most manufacturing SMEs due to improper planning and the absence of favourable investment climate necessary for these policies to be effective.
\end{abstract}

Keywords: SMEs, Government, Trade liberalisation, Manufacturing, Nigerian, Policy, Export

\section{Introduction}

The aim of this article is to present some initial findings from a longitudinal study of the impact of economic liberalisation on Small and medium sized enterprises (SMEs) development in Nigeria. The study motivated by the fact that SMEs in Nigeria and elsewhere are recognized as one of the principal driving forces in sustainable economic development because of their role in job creation, stimulation of entrepreneurial skills and private ownership of businesses (Udechukwu, 2003, Katwalo and Madichie, 2008). Due to their size and innovativeness SMEs are able to adapt to changes in market conditions besides helping to diversify the economy through exports and international trade (UNECE, 2003). Udechukwu (2003) also asserts that SMEs development is an essential element in the growth strategy of most economies and holds particular significance for developing countries like Nigeria because they are flexible to market changes. It has been suggested that the increasing prevalence of the flexibility and specialisation of SMEs persuades many business analysts to believe in SMEs' strategic role in the industrial structure of developing nations (Berry, 2002). But due to their small size and meagre financial bases, they remain rather vulnerable to external shocks often experienced in the global market as a result of trade liberalisation (Madichie, 2007; Vickery, 2008). Therefore, given favourable policy environment there is reasonable assurance that SMEs can compete successfully both in the local and global market (Briggs, 2007). Base on this premise, the Nigerian government embarked upon trade liberalisation with the aim of allowing SMEs which are considered to be more efficient in adapting to market/environmental changes than large firms to develop and grow in a competitive business environment created by the liberalisation policy (Dawson, 1994).

Trade liberalisation is the measure taken by the government to reduce anti-export bias, import controls a well as non-tariff barriers and exchange rate distortions (Santos-Paulino and Thirlwall, 2004, F51). The Nigerian government implemented trade liberalisation in order to create a competitive business environment with the removal of restrictions on international trade, capital flow and interest rates, deregulation of price control in the commodity market and the privatization of all government parastatal. Since trade liberalisation is also accompanied by currency devaluation, the Nigerian government also adopted the floating exchange rate in place of the administratively managed (adjustable peg) exchange system (Odusola and Akinlo, 2001; Agbeyegbe, Stotsky and WoldeMariam, 2006). The deregulation process proceeded simultaneously in all sectors of the economy with the exception of the labour market (Akinlo, 1996).

This paper discusses trade liberalisation policy and government development schemes introduced by the Nigerian government for SMEs development as a result of the implementation of the policy. It questions why programmes designed by the government under the trade liberalisation package have so far failed to achieve tangible results. This then necessitates the need for this paper to assess the possible/ plausible causes for these failures. In view of the factors responsible for SMEs' programme failures. Drawing from a sample of 500 Lagos-based manufacturing SMEs 
investigated over 1986 to 2006, the study examines how SMEs in Nigeria can exploit export opportunities in the international market under a liberalised trade regime.

\section{Review of related literature}

Trade liberalisation is an important component of Structural Adjustment Programme (SAP), aimed at opening up economies to increased international trade by either reducing or eliminating protection for domestic industries (Jubilee Australia, 2006). In addition, the policy is often implemented along with the devaluation of currency in order to make the exports of the devaluing country's export cheaper in the international market (Agbeyegbe, Stotsky and WoldeMariam, 2006; Obadan, 2006). The ultimate aim is to remove taxes on exports, restrictions on imports and the reduction of import tariffs. Sachs and Warner (1995) using a cross-country growth model argued that trade liberalisation leads to higher growth rates in poorer countries than in richer countries. In the same vein, Ajayi (2003) reports that the removal of barriers to trade has increased the flow of trade by 16 -fold in the last 50 years with the world exports of goods and services almost tripled in real terms between 1970 and year 2000. However, the share of developing countries contribution to world trade is still very low because their exports are predominantly primary products. In another study, Dollar (1992) linked economies that are outward-oriented through liberalised trade with rapid economic growth. Greenaway, Morgan and Wright (2002) evaluated the impact of trade liberalisation on 70 developing countries and found a significant positive relationship between trade liberalisation and economic growth.

Nishimizu and Robinson (1984) study on trade policies and productivity change in semi-industrialised countries explored the impact of trade regimes on total factor productivity (TFP) growth within a quantitative framework in a study of four countries, namely Korea, Turkey, former Yugoslavia and Japan as the comparator. The analysis of the inter-industry differences in TFP growth rates at the two-digital level, found that substantial portions of variation in TFP growth rates can be explained by the output growth allocated to export expansion and import substitution in Korea, Turkey and former Yugoslavia, but interestingly not in Japan. They concluded that import substitution regimes seem to be negatively correlated with TFP change, whereas export expansion regimes are positively correlated with TFP changes. In another study by Kruger and Tuncer (1982) on Turkey, sectoral level data were used to provide support that trade liberalisation improves efficiency. They concluded that periods of faster growth in total factor productivity coincided with periods of greater liberalisation.

Frankel and Romer (1999) and Irwin and Tervio (2002) in their separate and independent studies also suggest that countries that are more open to trade tend to experience higher growth rates and per capita incomes than closed economies. Klenow and Rodriguez-clare (1997) used general equilibrium model to establish that a greater number of intermediate input combinations results in productivity gains and higher output, despite using the same capital and labour inputs which exhibits the economics increasing returns to scale.

However, there are other arguments that suggest that trade liberalisation improves resource allocation in the short run or raise growth rates permanently as there are other arguments that suggest the contrary. Rodriguez and Rodrik (2000) argued that trade policies do affect the volume of trade, but there is no strong reason to expect the effect on growth to be quantitatively or qualitatively similar to the consequences of changes in trade volumes that arise as reductions in transport costs or increases in world demand. Trade restrictions represent policy responses to real or perceived market imperfections or are used as mechanisms for rent-extraction. They believe that trade policies work differently from natural or geographical barriers to trade and other exogenous determinants. Khan and Zahler (1985) asserts that trade can promote growth from the supply side but, if the balance of payments worsens due to fall in the price of the country's tradable, growth may be adversely affected from the demand side because the payments deficits resulting from liberalisation are unsustainable and cannot be easily corrected by relative price of non-tradable or real exchange rate adjustments.

In another stimulating study, Weisbrot and Baker (2002) argue that trade liberalisation may not be the only key to rapid economic growth and development. They noted that the success of some countries that experienced accelerated growth did not follow a simple path of trade liberalisation because the government directed the economy through the use of subsidies, protection for favoured industries and restriction on capital account flows. Rodrik (1998) asserts that the growth performance of those Asian countries that gained from open trade can be attributed to how they managed key macroeconomic shocks rather than trade policy alone.

Shafaeddin (2005) posits that trade liberalisation is necessary when an industry reaches a certain level of maturity provided it is undertaken gradually and selectively. However, Bretton Wood institution's methodology of liberalisation is likely to lead to the destruction of infant industries as well as hamper the emergence of new ones - a situation that would only serve to confine low income countries to the production and exports of primary commodities. This assertion captures the prevailing situation in most countries in Sub Sahara Africa (SSA) especially Nigeria that implemented rapid trade liberalisation. This is because Nigeria has lost its competitive manufacturing edge due to the demise most SMEs and has become increasingly dependent on petroleum as the major source of foreign exchange (Albaladejo, 2003). 
Winters (2004) pointed out that the methodological problems of previous studies linking liberalized trade to higher income creates some uncertainties because cross-country studies have difficulty in measuring openness, establishing causality and isolating the effects of trade liberalisation. He went further to state that trade liberalisation alone is not sufficient to boost growth but can only work when accompanied by other policies that ensure safe business and political environment besides a good regulatory legal framework that protects all stakeholders in the economy. In the same vein, Hübler, Menkhoff, and Suwanaporn, (2008) report that the 'average effects' of cross-country regression hide different experiences of countries that have implemented liberalization and they suggested the need for the use of micro level data in the study of the effects of liberalization.

According to Thirlwall (2000, pp. 6), "There can be little doubt that, historically, trade has acted as an important engine of growth for countries at different stages of development, not only by contributing to a more efficient allocation of resources within countries, but also by transmitting growth from one part of the world to another. Not all countries ... share equally in the growth of trade or its benefits. This will depend on: the production and demand characteristics of the goods that a country produces and trades; the domestic economic policies pursued, and the trading regime it adopts". Looking at the various arguments, the Nigerian government has extensively implemented policies aimed at ensuring an open market economy in order to encourage competition and the needed economic growth. But to what extent has the government pursued and implemented policies that ensure adequate provision of infrastructure for SMEs on the backdrop of the neo-liberal policy that preclude it from provision of public goods in Nigeria? This and other questions will be clearly explored from the findings of this study.

\section{Methodology}

To achieve its objectives, this paper utilised a structured questionnaire survey administered to 500 manufacturing SMEs operating in Lagos State to achieve its objectives. The questionnaire was design by the researcher for the purpose of this study and was divided into five sections with each section dealing with each variable that affects the performance of manufacturing SMEs that we set out to explore. A total of 369 valid responses were received which represent 73.8 percent. Interviews were conducted on 50 SMEs among the 369 respondents that granted the request to be interviewed in their questionnaires.

This survey was able to achieve this modest rate of response because the researcher employed the services of 10 Survey Attendants to administer and collect the questionnaires. The Survey Attendants were given 50 questionnaires each to administer to the respondents. The questionnaires were dropped and collected same day or dropped and picked the following day or at times at a later date depending on the respondents. To ensure high return rate and that the questionnaires were not left in the hands of the respondents, the Survey Attendants were advised to administer an average of 5 questionnaires in one day. A log of all the questionnaires were kept in order to keep track of the number of questionnaire administered and returned, ensure commitment and sincerity of the Survey Attendants while at the same time protect the identities of the sampled SMEs. In addition, the Survey Attendants were given the choice to pick the sample area for the survey they wish to administer the questionnaire assigned to them based on their residential propinquity to the sample areas. As a follow up to the structured questionnaires, interviews were conducted on 50 SMEs from the 369 respondents that granted the request to be interviewed in the returned. The questionnaire survey and structured interviews took a period of six months, between June and December 2007.

The survey was selective and purposive because the survey targeted only manufacturing SMEs irrespective of their line of products and also due to time and budget constraints. Lagos State was divided into five areas (clusters) for this purpose with more questionnaires distributed in areas with higher concentration of manufacturing SMEs. Only SMEs engaged in manufacturing activities were sampled and some of the returned questionnaires were invalidated because they were mistakenly administered to SMEs in the service sector or because the sampled firms cannot be classified as either small or medium sized enterprises due to the number of employees or capital base.

Prior to the questionnaire survey and structured interview, a pilot survey was conducted on 50 manufacturing SMEs in November 2006 in Ibadan, Oyo State of Nigeria. The preliminary survey was undertaken to validate and test whether the survey questionnaire designed for the study was properly done to capture the information needed to achieve the objectives of the study. It was at the pilot stage that it was observed that most of SMEs that participated were not comfortable giving out certain information such as sales, profit and cost figures which were vital for attaining the objectives of the study.

This observation partly informed the amendments in terms of reframing; reducing the number of questions and the removal of some of the areas most SMEs were not comfortable with. As a result, the decision to use structured interview to support the questionnaire survey which would enable the researcher specifically request those information from the willing sampled SMEs in the questionnaire survey was also taken after the pilot study.

The data obtained from this primary source was triangulated with secondary data from the Central Bank of Nigeria $(\mathrm{CBN})$, while the presentation of data was purely descriptive. Given time and budget constraints, the study limited the 
survey to SMEs operating in Lagos - a city chosen owing to the fact that it has the highest concentration of SMEs in Nigeria. It is pertinent to also point out that the emphasis of the methodology is not to present a statistically representative result considering the population and size of Nigeria (with over 120 million), but to highlight the main obstacles preventing SMEs exploring opportunities abroad and hence perpetuating their 'permanent infancy' and ultimate mortality - even in the face of a well planned liberalised trade regime by various Nigerian government.

\section{Trade liberalization and government development schemes for SMEs}

The Nigerian government, since 1986 implemented various programmes such as exchange rate deregulation, removal of import and export licenses and Small Scale Industrial Credit Scheme (SSICSs), aimed at assisting the development of SMEs as part of trade liberalisation policy (Dawson, 1994). Part of the trade liberalisation policy was envisaged would pave the way for a competitive business environment for SMEs and Multinational Corporations (MNCs) in Nigeria. The liberalisation policy was aimed at making locally manufactured product more competitive both in the domestic and international market. While the removal of restrictions on imports was to allow free flow of goods and investments in order to make raw materials cheap and available to manufacturing SMEs (Vachani, 1994). The policy was also to encourage SMEs explore export opportunities that would help reduce government dependence on petroleum as the major source of foreign exchange. Despite these programmes, it has been observed that their impact on the performance of SMEs have been less than satisfactory (Mambula, 2002). This is attributable to some factors that governments and policy makers in Nigeria have failed to take into consideration in the design and implementation of SME development programmes. Most SMEs in Nigeria either remain small, moribund or shut down within few years of operation. In particular, this phenomenon has become more prevalent under the liberalised trade arrangements occasioned by Structural Adjustment Programme (SAP) (Ekpenyong, 2002; Rodriguez and Berry, 2002).

The dismal results of the series of government programmes for SMEs development and the inability of the manufacturing SMEs to sustain domestic market needs for manufactured goods in Nigeria became evident in the early 1980s following the fall in the international market price for crude oil. The drop in revenue from the sale of crude oil resulted in the inability of the Nigerian government to meet her import bills. This then led to a serious balance of payment deficit exacerbated by the absence of active private sector to provide domestic substitutes for imported goods (Adenikiju and Chete, 2002). The realisation of this vital role of the private sector (SMEs) necessitated the need for economic reform that culminated in trade liberalisation.

The economic reform process commenced with the implementation of SAP in 1986 by the Nigerian government on the recommendation of the Bretton Woods Institutions - notably the International Monetary Fund (IMF) and the World Bank (Okome, 1999). It has been argued that liberalisation is an unwritten requirement for economic integration which is the conditional lending policy of IMF based on adherence to SAP (Aisbett, 2003). The main objective of the SAP in Nigeria was to introduce locally manufactured products to the international market through increased local output (Madeley, 2000). This programme led to the complete liberalisation of the Nigerian economy which prompted the government to remove all forms of protection for SMEs in terms of sourcing for raw materials, finance and foreign exchange. This resulted in the increase in the cost of financing imported input which compelled SMEs and other local producers to source production inputs locally (Dawson, 1994; Madichie, 2008).

Prior to the reform, it was widely believed that the Nigerian economy was highly controlled by the government through import and export restrictions, regulation of interest rates and exchange rates through the CBN (Akinlo and Odusola, 2003). The deregulation exercise was then envisaged would create a level playing ground that would enhance competition and eliminate wastage of scare resources. Thereby increase SMEs participation towards sustainable economic development in Nigeria through greater export of their products. The deregulation exercise instead of improving access to foreign exchange, created gap between the official and parallel exchange rate that constituted a disincentive to export-oriented policy of the Nigerian government against potential exporters (Akinlo and Odusola, 2003; Briggs, 2007).

Other development programmes for SMEs include the setting up of industrial estates, establishment of specialised financial institutions such as the Small Scale Industrial Credit Scheme (SSICSs), Small and Medium Industry Equity Investment Scheme (SMIEIS), Nigerian Industrial Development Bank (NIDB), Nigerian Bank for Commerce and Industry (NBCI) to provide long-term credit to SMEs, the National Economic Reconstruction Fund (NERFUND) set up in 1990 to grant medium to long-term local and foreign loans to SMEs located in the rural areas (Anyanwu, 2003; Briggs, 2007).

In the formulation and implementation of these incentive schemes aimed at encouraging SMEs both for domestic and exports production, infrastructures were left out of the scheme. It is obvious that the availability of infrastructure contributes positively to SMEs performance because it represents an intermediate input to production. Infrastructure quality affects the profitability of production, level of income, output and employment creation and hence poverty alleviation (Adenikinju, 2005). The responsibility for the provision of enabling business environment; hence infrastructure lies with the government. But this has changed in recent times with the governments' adoption of the 
IMF/World Bank policy of SAP anchored on neo-liberal economic policy. The policy precludes the government from direct participation in economic activities - a move that has resulted in the deplorable condition of infrastructure in Nigeria owing to poor budgetary outlays towards expansion and rehabilitation of existing ones (Lee and Anas 1992; Agboli and Ukaegbu, 2006). This state of infrastructure has adversely affected the profitability performance of SMEs.

It should be noted that trade and financial market liberalisation were pursued at the same time in Nigeria. An approach Ayadi and Hyman (2006) assert that the government implemented so many policies within a short space of time. McCulloch et al, (2001) observed that governments in developing countries pursued macroeconomic stabilisation and adjustment programmes simultaneously which contained different forms of liberalisation. The idea of exchange rate liberalisation in Nigeria was to make imports less attractive with the resultant low value of the naira. However, the import oriented consumption pattern of Nigerian population makes this unworkable (Akinlo and Odusola, 2003). This is because the effectiveness of exchange rate deregulation in reducing import requires that the import elasticity of demand be greater than one which is contrary to the import demand in Nigeria. This coupled with the free flow of finished goods militated against manufacturing SMEs competitiveness after liberalisation.

\section{Data presentation and analysis}

This section, presents the information from the data of the study analysed using Statistical Packages for Social Science (SPSS) 16.0.

\subsection{Characteristics of Sampled Firms}

From table 1, 107 directors of sampled firms participated in filling out the questionnaires which represents $29 \%$ of total valid sample. While 173 managers representing $46.9 \%$ filled the questionnaire. The number of secretaries and other officials of sampled firm that filled the questionnaires in place of director and mangers are 41 and 48 representing $11.1 \%$ and $13 \%$ respectively.

In terms of the age of sampled firms, a total of 51 SMEs representing $13.8 \%$ fall into firms that have been in existence for 21 years and over. The economic reform process that culminated in the complete liberalisation of the Nigerian economy commenced in 1986 which leaves us with 51 SMEs out of the 369 sampled SMEs to obtain retrospective information on changes from 1986 to 2006. A total of 115 and 103 sampled SMEs fall under the category of businesses that were established within the past 10 years, put together represents $59.1 \%$ of sampled firms. A total number of 62 and 38 firms fall into the category of businesses established within the past 20 years and represents $27.1 \%$ of sample. The trend gives an indication that only few businesses among the ones sampled have been able to survive through the years of economic reforms process in Nigeria.

It was observed from the survey questionnaire that 176 firms representing $47.7 \%$ of sampled SMEs are into manufacturing alone. This means that they have manufacturers' representatives who have outlets to help sell their products on their behalves. A total of 193 representing 52.3\% manufacture and also distribute their products in addition to having manufacturers' representatives. Apart from this, the outputs of some of the sampled SMEs are not large enough to warrant the use of manufacturers' representatives. Those that manufacture and at the same time retail their products see the measure as a strategy to eliminate middle men so as to reduce final product price and in order to gain more market share. These firms are already faced with stiff competition from imported finished products and the only way they can survive is to sell their manufactured products on their own. Besides they claim that most of the retailers shun their products because of the very small margin of profit compared to the imported products which gives more profit margins to the retailers. Besides Nigerians prefer buying imported products some because of the ecstatic value attached them apart from their quality.

\subsection{Impact of Liberalisation on Sampled SMEs}

From Table 2, it can clearly be seen that despite the concession on duty on imported raw materials by the Nigerian government, $51.5 \%$ of the surveyed SMEs still source their raw materials locally as opposed to only $6.2 \%$ that depended on imports. In a worse case scenario $42.3 \%$ obtained their raw materials from both local and international sources thereby spreading their risk portfolio in the event of another government u-turn. It was also observed that the depreciation of the Naira (the unit of currency in Nigeria) increased the cost of sourcing raw materials from abroad - a situation that has only served to compound the already high costs of production, which more often than not is reflected in the final product prices. They are then compelled to make use of local raw materials and in some cases re-cycle some input materials such as plastics and tins. This result is consistent with Dawson (1994) that reported an increase in the use of re-cycled product by SMEs.

The majority of the sampled SMEs experienced increase in production which represents $66.1 \%$ while $24 \%$ experienced decrease after the implementation of trade liberalisation. Those that experience decrease in production level attributes this to the fact that they were engage in the production of goods that were close substitutes to cheaper imports from abroad. In terms of selling their products on the international market, only $14.9 \%$ export their products to the neighbouring West African countries while $85.1 \%$ sell their products in the domestic market. Despite the fact that 
$66.1 \%$ experienced increase in production, $44.4 \%$ experienced decrease in turnover as against the $36.9 \%$ that achieved increase in turnover while $18.7 \%$ did not notice any change in turnover. The decreases in turnover are in congruence with the trend of reported decrease in profit level as $78.6 \%$ of respondents reported decrease in profit as against just $8.4 \%$ that experienced increase in profit. Those that did not notice any changes in profit level represent $13 \%$ of sampled SMEs. This is contrary to Akinlo and Odusola (2003) study that revealed a decrease in production level but consistent with the decrease in turnover that was reported in this study.

The respondents also pointed out that the increase in production was an attempt to take advantage of the increased market and availability of cheap labour following trade liberalisation. Unfortunately most SMEs were not better off for two main reasons: First, they often faced with accumulated inventory due to low demand occasioned by the fall in real income of the population as a result of the depreciating naira. Second, the cost of production also contributed drastically in eroding the profit of SMEs. The respondents linked this pathetic situation to erratic power supply since they had to channel some of their resources to generating their own power. In addition, the absence of cheap indigenous technology that would have eased their production cost compels them to import production machinery at exorbitant prices. These machines due to high replacement costs are continuously used well over their economic useful lives. Ekpenyong (2002) study on the impact of SAP on SMEs in Nigeria also revealed drop in sales due to poor purchasing power of Nigerian following rising inflation as result of the devaluation of the naira. The increased cost of operation observed in this study, supports the findings of Lee and Anas (1992); Agboli and Ukaegbu (2006) who found in their study that the trade policy led to low budgetary allocation for the maintenance of infrastructure by the government. This has resulted in the deplorable state of infrastructure and compels most SMEs to spend substantial part of their resources/profit on self provision of needed facilities.

\section{Conclusions and implication}

It has become clear that the primary reasons for the failure of SMEs schemes in Nigeria are not particularly unique lack of involvement in the planning process inadvertently leads to lack of trust or trepidation which creates a situation of 'them' and 'us'. Among the common symptoms to the problems of manufacturing SMEs in Nigeria are (i) poor access to finance - mostly due to the inability of the legal and regulatory framework to protect creditors (Banks) against loan default from SMEs bad debt. This has prompted banks to request for collaterals beyond what SMEs can provide; (ii) the inability of SMEs to seek professional advice or employ a skilled labour force (as a result of small budgets) to manage specialised areas of their business such as bookkeeping; (iii) inability to prepare feasibility studies which makes some of them venture into businesses with neither prior knowledge of the business concept nor any idea of the cost implications; (iv) inconsistency in the application of government policies for SMEs development - i.e. the lack of information on the real needs and operational difficulties of SMEs by the government agencies responsible for the design and implementation of SME development programmes - most of which were often designed without putting into consideration the peculiar nature and level of education of supposed beneficiaries.

Moreover in the absence of functional infrastructure such as steady power supply, portable water supply, good access roads, telecommunication network especially in the rural areas, and the chances of SMEs exploring and competing favourably in the international market are very limited. The depreciation of the naira with the resultant increase in the price of raw materials and imported production equipment coupled with the absence of indigenous technology make SMEs rely on imported capital equipment which further worsens their chances in the international marketplace. The conclusions of this study are consistent with a study undertaken about five years ago - where Albaladejo (2003) argued that Nigeria had lost her competitive manufacturing edge in the non-oil sector. Available record from the CBN indicates that export of petroleum products has persistently contributed to the lion share of Nigeria's total export and stood at about $95 \%$ in the last quarter of 2004 while the non-oil export continues to trail behind with an all time low performance in 1994 of $2.6 \%$ of total exports since 1980 (CBN 2004). In order to hasten the diversification of the Nigerian economy from the huge dependence on oil money, the government needs to leverage the oil money into tangible investments such as the provision of infrastructure conducive to manufacturing - a sector that has now become dominated by SMEs - who have also become highest employers but ironically remain uncompetitive in the regional and international markets.

\section{Acknowledgement}

The Author wishes to acknowledge the contributions of Dr Nompumelelo Obokoh for editing the paper, Dr Kyaruzi Imani, participants at the 2008 IAABD conference held at the University of Florida, USA and two anonymous referees for their insightful comments on previous version of this paper. 


\section{References}

Adenikinju, A.F. (2005). Productivity Performance in Developing Countries: Country Case Studies, Nigeria. United Nations Industrial Development Organisation.

Adenikinju, A.F., \& Chete, L.N. (2002). Productivity, Market Structure and Trade Liberalisation in Nigeria. AERC Research Paper 126, African Economic Research Consortium, Nairobi.

Adjustment Program, 1986-1993. West Africa Review: [Online] Available at http://www.icaap.org/iuicode?101.1.1.9] (November 17, 2005).

Agbeyegbe, T.D, Stotsky, J. \& WoldeMariam, A. (2006). "Trade liberalisation, exchange rate changes, and tax revenue in Sub-Saharan Africa”, Journal of Asian Economics, Vol. 17, pp. 261-284.

Agboli, M. \& Ukaegbu, C.C. (2006). Business Environment and Entrepreneurial Activity in Nigeria: Implications for Industrial Development. Journal of Modern African Studies, Vol. 44, No. 1, pp. 1-30.

Aisbett, E. (2003). Globalization, Poverty and Inequality: are the criticisms vague, vested, or valid? A Paper prepared for the NBER Pre-conference on Globalization, Poverty and Inequality.

Ajayi, S. I. (2003). Globalisation and Africa. Journal of African Economies, Vol. 12, pp. 120-150.

Ajibefun, I.A., \& Daramola, A.G. (2003). Efficiency of Microentreprises in Nigerian Economy. AERC Research Paper 134, African Economic Research Consortium, Nairobi.

Akinlo, A. E., \& Odusola, A. F. (2003). Assessing the impact of Nigeria's Naira Depreciation on Output \& Inflation. Applied Economics, Vol. 35, No. 6, pp. $691-703$.

Akinlo, A.E. (1996). The Impact of Adjustment Programme on Manufacturing Industries in Nigeria, 1986-1991: A Sample Study. African Development Review, Vol. 16, pp. 73-93.

Albaladejo, M. (2003). Industrial Realities in Nigeria: From Bad to Worse. QEH Working Paper Series QEHWPS101, pp. $1-23$.

Anyanwu C.M. (2003). The Role of Central Bank of Nigeria in Enterprises Financing in Central Bank of Nigeria (Eds) Seminar on Small and Medium Industries Equity Investment Scheme (SMIEIS) CBN training Centre, Lagos. pp. 20-31.

Ayadi, O.F., \& Hyman, L. (2006). "Financial Liberalization and Price Rigidity in the Nigerian Banking System," Managerial Financial, Vol. 32 (7), 557-568.

Berry, A. (2002). The Role of the Small and Medium Enterprise Sector in Latin America and Similar Developing Economies. Seton Hall Journal of Diplomacy and International Relations, pp. 104-119.

Briggs, I. N. (2007). Nigeria: Mainstreaming Trade Policy into National Development Strategies. African Trade Policy Centre (ATPC) Work in Progress No.52, Economic Commission for Africa. Brookings Papers on Economic Activity; No.1; ABI/INFORM Global pg. 1Business Management, Vol. 40, No. 1, pp. 58-65.

CBN (2005). Central Bank of Nigeria Statistical Bulletin. 15, Abuja.

Dawson, J. (1994). Responses to Adjustment- the Marginalisation of Small Enterprises in Nigeria. Small Business Enterprise Development, Vol. 5, No. 2, pp. 18-24.

Dollar, D. (1992). Outward-Oriented Developing Economies Really Do Grow More Rapidly: Evidence from 95 LDCs, 1976-85. Economic Development and Cultural Change, Vol. 40, No. 3, pp. 523-544.

Egwaikhide, F.O. (1999). Determinants of imports in Nigeria: A dynamic specification. AERC Research Paper 91, African Economic Research Consortium, Nairobi.

Ekpenyong, D.B. (2002). Performance of Small Scale Enterprises in Nigeria during the Structural Adjustment Programme Implementation: Survey Findings. Journal of Financial Management \& Analysis, Vol. 15, No. 1, pp. 38-50.

Frankel, J., \& Romer, D., (1999). Does Trade Cause Growth?. American Economic Review, Vol. 89, No. 3, pp. 379-399.

Greenaway D., Morgan, W. \& Wright, W. P. (2002). Trade Liberalisation and Growth in Developing Countries. Journal of Development Economics, Vol. 67, pp. 229-244.

Hübler, O., Menkhoff, L. \& Suwanaporn, C. (2008), "Financial Liberalisation in EmergingMarkets: How Does Bank Lending Change?" The World Economy, pp. 393-415.

Irwin, D. A., \& Tervio M. (2002). Does Trade Raise Income? Evidence from the Twentieth Century. Journal of International Economics, Vol. 58, No.1, pp. 1-18.

Jubilee,Australia.(2006). Drop the Debt: Debt Jargon. [Online] Available at http://www.jubileeaustralia.org/512_jubilee_debt_jargon.php (April 4, 2007). 
Katwalo, A.M \& Madichie, N. O. (2008). Entrepreneurial and cultural dynamics: a gender kaleidoscope of Ugandan Microenterprise. International Journal of Entrepreneurship and Small Business. Vol. 5, No. 3/ 4, pp. 337-348.

Khan, M.S. \& Zahler, R. (1985). Trade and Financial Liberalisation Given External Shocks and Inconsistent Domestic Policies. IMF Staff Papers, Vol. 32, pp. 22-55.

Klenow, P. J. \& Rodriguez-Clare, A. (1997). Quantifying Variety Gains from Trade Liberalisation. Graduate School of Business, University of Chicago, unpublished.

Kruger, A.O. \& Tuncer, B., (1982). An Empirical Test of the Infant Industry Argument. American Economic Review, Vol. 72, No. 5, pp. 1142-1152.

Lee, K.S., \& Anas A. (1992). Costs of Deficient Infrastructure: The Case of Nigerian Manufacturing. Urban Studies, Vol. 29, No. 7, pp. 1071-1092 (22).

Madeley, J. (2000). Trade and Hunger: An Overview of Case Studies on the Impact of Trade Liberalisation on Food Security. [Online] Available at www.forumsyd.se (May 20, 2006).

Madichie, N. (2007). Better off out? Costs and benefits of sub-Saharan Africa's membership of the World Trade Organization. Journal of African Business, Vol. 8, No. 1, pp. 5-30.

Madichie, N. (2008). An Evaluation of the Country-of-Origin Effects on the Nigerian Guinness Brand. In: Veloutsou, C. \& Papadopoulos, N. (Eds.) Marketing in Dynamic Environments: Contemporary Research Advances. Athens, Greece: ATINER Press, Chapter 10, pp. 117-128.

Mambula, C. (2002). Perceptions of SME Growth Constraints in Nigeria. Journal of Small Business Management, Vol. 40 , No. 1 , pp. 58-65.

McCulloch, N.,Winters, L.A., \& Cirera, X. (2001). Trade Liberalisation and Poverty: A Handbook, Centre for Economic Policy Research. London.

Nigeria. In Central Bank of Nigeria (Eds) Seminar on Small and Medium Industries Equity Investment Scheme (SMIEIS) CBN training Centre, Lagos, pp. 6-18.

Nishimizu, M., \& Robinson, S., (1984). Trade Policies and Productivity Change in Semi-Industrialised Countries. Development Research Paper, World Bank.

Okome, Mojubaolu Olufunke. (1999). State and Civil Society in Nigeria in the Era of Structural

Rodriguez, E., \&Berry, A. (2002). SMEs and the New Economy: Philippine Manufacturing in the 1990s. In Charles Harvey and Boon-Chye Lee, (Eds), The Role of SMEs in National Economies in East Asia. Cheltenham: Edward Elgar.

Rodríguez, F., \& Rodrik, D. (2000). Trade Policy and Economic Growth: A Sceptic's Guide to the Cross-National Evidence. CEPR Discussion Paper, No. 2143. London, Centre for Economic Policy Research.

Rodrik, D. (1998). Trade Policy and Economic Performance in Sub-Saharan Africa. NBER

Sachs, J. D., \& Warner, A. (1995). Economic Reform and the Process of Global Integration.

Santos,Paulino,A.,\&Thirlwall, A. P. (2004). The Impact of Trade Liberalisation on Exports, Imports and the Balance of Payments of Developing Countries. The Economic Journal, Vol. 114, pp. F50-F72.

Shafaeddin, S.M. (2005). Trade Liberalisation and Economic Reform in Developing countries: Structural Change or De-Industrialization? Discussion Paper, No. 179, United Nations Conference on Trade and Development.

Thirlwall, A.P. (2000). Trade, Trade Liberalisation and Economic Growth: Theory and Evidence. Economic Research Paper, No. 63, the African Development Bank.

Udechukwu, F.N. (2003). Survey of Small and Medium Scale Industries and their Potentials in.

UNECE (2003). Small and Medium-Sized Enterprises in Countries in Transition. United Nations Economic Commission for Europe Series: Entrepreneurship and SMEs, United Nations, New York and Geneva.

Vachani, S. (1994). The Impact of Economic Liberalisation on Small Companies' Competitiveness. Small Business Enterprise Development, Vol. 5, No. 2, pp. 41-46.

Vickery, J. (2008). How and why do Small Firms Manage Interest Rate Risk? Journal of Financial Economics, 87, pp. 446-470.

Weisbrot, M., \& Baker, D. (2002). The Relative Impact of Trade Liberalisation on Developing countries. Center For Economic and Policy Research, Washington D.C.

Winters, L. A. (2004). Trade Liberalisation and Economic Performance: An Overview. EconomicJournal, Vol. 114, pp. F4-F21.Working Paper 6562, Cambridge, MA: National Bureau of Economic Research. 


\section{Appendix}

Table 1. Showing characteristics of sampled firms

\begin{tabular}{|c|c|c|}
\hline Position of Officers in the Firms & Frequency & Percentage \\
\hline Director & 107 & 29.0 \\
Manager & 173 & 46.9 \\
Secretary & 41 & 11.1 \\
Other Officers & 48 & 100 \\
Total & 369 & \\
\hline Age of Company (in years) & & 31.2 \\
01-05 & 115 & 27.9 \\
06-10 & 103 & 16.8 \\
$11-15$ & 62 & 10.3 \\
$16-20$ & 38 & 6.8 \\
$21-25$ & 25 & 4.6 \\
$26-30$ & 17 & 2.4 \\
Above 30 & 9 & 100 \\
Total & 369 & 47.7 \\
\hline Line of Business & 193 & 52.3 \\
Manufacturing & 369 & 100 \\
\hline Total & & \\
\hline
\end{tabular}

Source: Field Survey 2007

Table 2. Impact of trade liberalisation on sampled SMEs

\begin{tabular}{|c|c|c|}
\hline Item under consideration & No. of Firms & Percentage \\
\hline \multicolumn{3}{|l|}{ Source of Raw Material } \\
\hline Local & 190 & 51.5 \\
\hline International & 23 & 6.2 \\
\hline Local \& International & 156 & 42.3 \\
\hline Total & 369 & \\
\hline \multicolumn{3}{|l|}{ Change in Production After Liberalisation } \\
\hline Increase & 224 & 66.1 \\
\hline Decrease & 90 & 24.4 \\
\hline No Change & 35 & 9.5 \\
\hline Total & 369 & \\
\hline \multicolumn{3}{|l|}{ Export of Products Abroad } \\
\hline Yes & 55 & 14.9 \\
\hline No & 314 & 85.1 \\
\hline Total & 369 & \\
\hline \multicolumn{3}{|l|}{ Change in Turnover After Liberalisation } \\
\hline Increase & 136 & 36.9 \\
\hline Decrease & 164 & 44.4 \\
\hline No Change & 69 & 18.7 \\
\hline Total & 369 & \\
\hline
\end{tabular}




\begin{tabular}{|c|c|c|}
\hline Change in Profit & & 8.4 \\
Increase & 31 & 78.6 \\
Decrease & 290 & 13.0 \\
No Change & 48 & \\
Total & 369 & \\
\hline
\end{tabular}

Source: Field Survey 2007

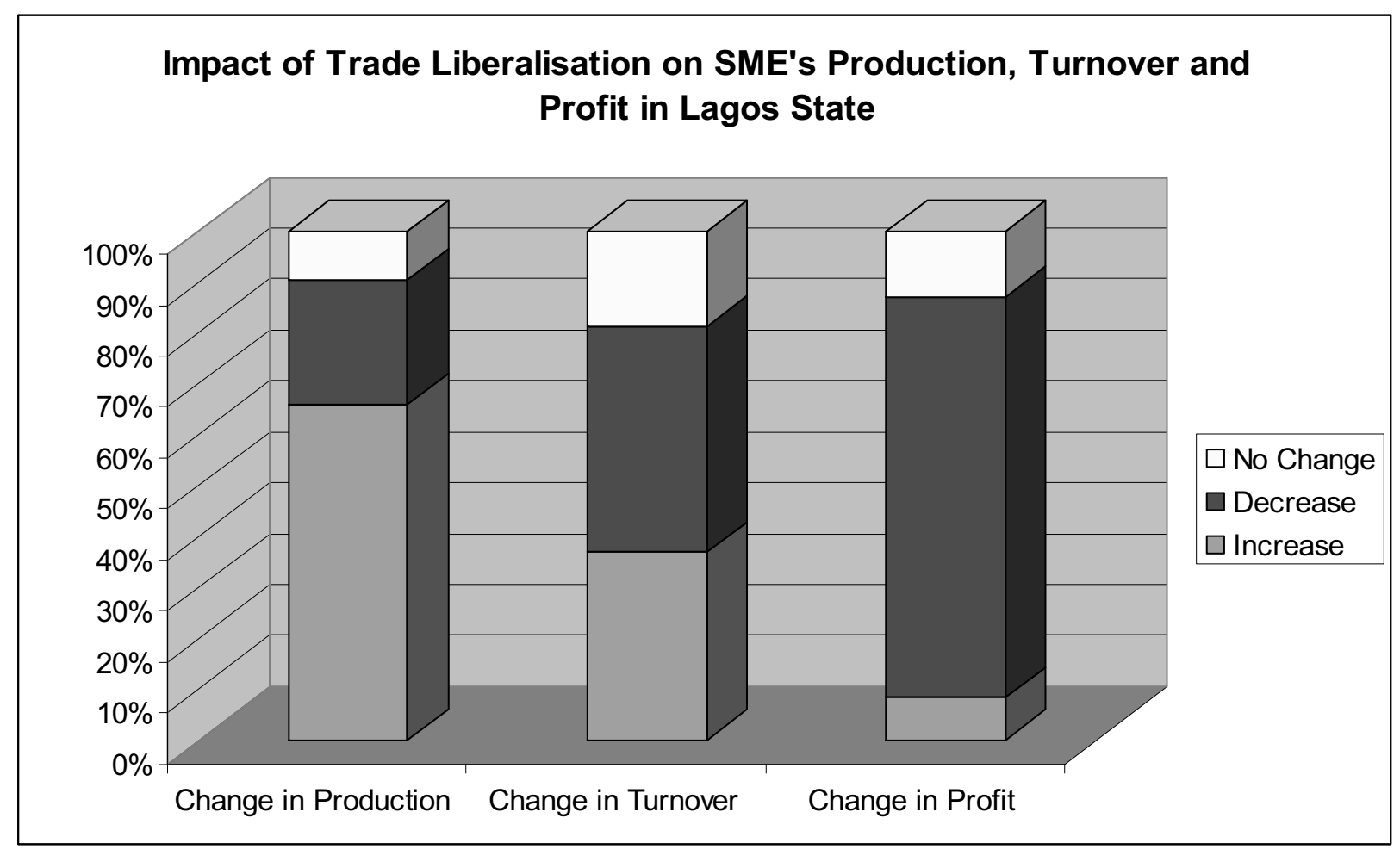

Figure 1. Graphical Representation of the impact of trade liberalisation on sampled SME's in Lagos State from table 2 